JURNAL PENDIDIKAN, p-ISSN 2715-095X, e-ISSN 2686-5041

Volume 29, No.2, Juli 2020 (143-150)

Online: http:// journal. univetbantara. ac. id/index. php/jp

\title{
Peningkatan Hasil Belajar Biologi Materi Sistem Pernapasan Melalui Model Problem Based Learning Bagi Peserta Didik Kelas XI MIPA 6 SMA Negeri 1 Tawangsari Semester 2 Tahun Pelajaran 2017/2018
}

\section{Sri Mulyani}

Guru SMA Negeri 1 Tawangsari Kabupaten Sukoharjo, email:mulyanisri944@yahoo.com

\begin{abstract}
Abstrak: Penelitian ini merupakan Penelitian Tindakan kelas, yang bertujuan untuk meningkatkan proses pembelajaran biologi dan hasil belajar melalui model pembelajaran Problem Based Learning. Subjek penelitian adalah peserta didik kelas XI MIPA 6 SMA Negeri 1 Tawangsari semester 2 yang berjumlah 38 peserta didik. Teknik pengumpulan data dengan menggunakan metode tes tertulis, observasi, dan dokumentasi. Adapun prosedur penelitian dilakukan melalui dua siklus, dan setiap siklus terdiri dari perencanaan, pelaksanaan tindakan, observasi, dan refleksi. Hasil penelitian: (1) terjadi peningkatan motivasi peserta didik dalam pembelajaran yaitu $31,58 \%$ pada prasiklus, dan 92,11\% pada siklus II; (2) terjadi peningkatan keaktifan peserta didik dalam pembelajaran yaitu $31,58 \%$ pada prasiklus, dan $89,47 \%$ pada siklus II; (3) terjadi peningkatan pencapaian ketuntasan belajar peserta didik bila dibandingkan antara prasiklus yaitu $55,26 \%$ pada prasiklus, dan $86,84 \%$ pada siklus II. Terjadi peningkatan pencapaian nilai rata-rata bila dibandingkan antara prasiklus 69,74 , di akhir siklus II menjadi 80,00. Simpulan penelitian ini adalah penerapan model pembelajaran Problem Based Learning dapat meningkatkan kualitas proses pembelajaran dan hasil belajar biologi materi sistem pernapasan.
\end{abstract}

Kata-kata Kunci: Hasil belajar, model Problem Based Learning

\section{Improvement of Biology Learning Outcomes About Respiratory System Material Through The Problem Based Learning Model for Class XI MIPA 6 Students of SMA Negeri 1 Tawangsari Semester 2 for 2017/2018 Academic Year}

\begin{abstract}
Sri Mulyani
Teacher of SMA Negeri 1 Tawangsari, Sukoharjo Regency, email:mulyanisri944@yahoo.com

Abstract: This research is a Classroom Action Research, which aims to improve biology learning process and outcomes through Problem Based Learning model. The research subjects were students of class XI MIPA 6 of SMA Negeri 1 Tawangsari in semester 2 of 38 students. Data collection techniques by using the method of written tests, observations and documentation. The research procedure is carried out through two cycles, and each cycle consists of planning, implementation, observation and reflection. The results of the study: (1) an increase in student learning motivation when compared to pre-cycles ie $31,58 \%$, and at the end of cycle 2 becomes 92,11\%; (2) an increase in student learning activities when compared to pre-cycles ie $31,58 \%$, and at the end of cycle 2 becomes $89,47 \%$; (3) an increase in students' mastery learning achievement when compared to pre-cycles ie 55,26\%, and at the end of cycle 2 becomes $86,84 \%$. An increase in the achievement of the average value when compared to pre-cycle 69,74, and at the end of cycle 2 becomes 80,00. The conclusion of this research is that the application of the Problem Based Learning model can improve biology learning process and biology learning outcomes of respiratory system material.
\end{abstract}

Keywords: Learning Outcomes, Problem Based Learning model 


\section{Pendahuluan}

Seiring dengan perkembangan ilmu pengetahuan dan teknologi di era globalisasi yang semakin pesat, permasalahan yang muncul semakin beragam dan kompleks. Manusia harus tangguh dan mampu untuk berkompetensi menghadapi tantangan itu. Manusia harus mampu untuk mencari sendiri pemecahan masalah yang timbul dari dampak kemajuan zaman. Upaya menyiapkan manusia yang mampu berkompetensi untuk menghadapi kemajuan zaman adalah dengan membekali peserta didik dengan kemampuan memecahkan masalah. Menurut Wena (2011:53), kemampuan memecahkan masalah sangat penting artinya bagi peserta didik dan masa depannya. Berdasarkan data PISA (Programme for International Student Assessment) tahun 2012, dari 65 negara yang berpartisipasi, Indonesia menempati urutan ke-64. Data tersebut menunjukkan bahwa kualitas para pelajar Indonesia kini berada di posisi terendah. Peserta didik Indonesia mendapatkan nilai 375 untuk matematika, nilai 396 untuk membaca dan nilai untuk bidang sains adalah 382. Hasil studi PISA tersebut menunjukkan bahwa kemampuan penguasaan sains peserta didik di Indonesia masih rendah. Peserta didik Indonesia tidak biasa menghubungkan ilmu dengan permasalahan riil kehidupan. Upaya untuk membekali peserta didik dengan kemampuan memecahkan masalah di SMA Negeri 1 Tawangsari juga masih menghadapi kendala. Berdasarkan hasil analisis ulangan harian ketika peserta didik diberi soal-soal pemecahan masalah hanya sekitar 30\% yang dapat mengerjakan dengan baik. Hasil belajar yang diperoleh peserta didik juga masih rendah. Rata-rata nilai ulangan harian pada materi sistem pernapasan adalah 69,74 dan belum mencapai ketuntasan belajar minimal (KKM) yang ditetapkan yaitu 75 dengan ketuntasan belajar hanya 55,26\%

Salah satu upaya perlu dilakukan untuk mengatasi permasalahan rendahnya hasil belajar peserta didik, yaitu melalui model pembelajaran Problem Based Learning (PBL). $P B L$ merupakan model pembelajaran yang memberikan permasalahan kepada peserta didik untuk diselesaikan. Proses-proses dalam menyelesaikan masalah tersebut dapat memberikan sarana kepada peserta didik untuk melakukan penyelidikan dan inkuiri. Melalui penyelidikan tersebut peserta didik mendapatkan pengalaman belajar dan pengetahuan. Diharapkan melalui model PBL juga bisa membantu peserta didik untuk meningkatkan kemampuan dalam memecahkan masalah, sehingga bisa meningkatkan hasil belajar pada materi sistem pernapasan dan pada akhirnya bisa mengantarkan peserta didik untuk berkompetisi di era globalisasi. Pembelajaran biologi dengan penerapan model $P B L$ telah dilakukan oleh Wulandari dkk. (2014). Hasil penelitian menunjukkan bahwa penerapan model $P B L$ dapat meningkatkan aktivitas dan hasil belajar biologi. Model $P B L$ juga membantu peserta didik untuk mempunyai kemampuan memecahkan masalah. Hal ini telah diamati dalam jurnal yang ditulis oleh Hariatik dkk. (2017), bahwa pembelajaran biologi dengan model Problem Based Learning yang disertai Dialog Socrates dapat meningkatkan hasil belajar afektif, kognitif, dan psikomotor. Dialog Socrates (DS) menurut Van Rossem (dalam Hariatik dkk., 2017:47) adalah pembelajaran dengan proses diskusi yang dipimpin guru untuk membuat peserta didik mempertanyakan penalarannya atau untuk mencapai sebuah kesimpulan. Kemampuan memecahkan masalah perlu dimiliki oleh peserta didik karena kemampuan ini dapat membantu peserta didik membuat keputusan yang tepat, cermat, sistematis, logis, dan mempertimbangkan berbagai sudut pandang. Sebaliknya, kurangnya kemampuan ini mengakibatkan peserta didik pada kebiasaan melakukan berbagai kegiatan tanpa mengetahui tujuan dan alasan melakukannya (Hariatik dkk., 2017:49). 
Menurut Keller (dalam Abdurrohman, 2003:38), bahwa hasil belajar adalah keluaran dari suatu sistem pemrosesan berbagai masukan yang berupa informasi. Lebih lanjut Azwar (2007:11) menyatakan bahwa hasil belajar adalah hasil yang telah dicapai peserta didik dalam proses belajar mengajar yang dinyatakan dalam bentuk simbol, angka, atau huruf melalui suatu proses evaluasi. Bloom (dalam Sagala, 2003), mengklasifikasikan hasil belajar dalam tiga ranah yaitu ranah kognitif (cognitive domain), ranah afektif (affective domain) dan ranah psikomotorik (psychomotor domain). Hasil belajar dikatakan sempurna apabila memenuhi tiga aspek: kognitif, afektif dan psikomotor, sebaliknya dikatakan hasil belajar kurang memuaskan jika seseorang belum mampu memenuhi target dalam ketiga kriteria tersebut. Pembelajaran secara sederhana dapat diartikan sebagai produk interaksi berkelanjutan antara pengembangan dan pengalaman hidup. Makna yang lebih kompleks tentang pembelajaran pada hakikatnya adalah usaha sadar dari seorang guru untuk membelajarkan peserta didiknya (mengarahkan interaksi peserta didik dengan sumber belajar lainnya) dalam rangka mencapai tujuan yang diharapkan (Trianto, 2010). Pernyataan di atas sejalan dengan yang dikemukakan oleh Winataputra (2008), bahwa pembelajaran diartikan sebagai upaya sistematik dan sistemik untuk menciptakan lingkungan belajar yang potensial menghasilkan proses belajar yang bermuara pada berkembangnya potensi individu sebagai peserta didik. Lebih lanjut Aunurrahman (2009) menyatakan bahwa melalui proses pembelajaran, guru dituntut untuk mampu membimbing dan memfasilitasi peserta didik agar mereka dapat memahami kekuatan serta kemampuan yang mereka miliki, untuk selanjutnya memberikan motivasi agar peserta didik terdorong untuk bekerja atau belajar sebaik mungkin untuk mewujudkan keberhasilan berdasarkan kemampuan yang mereka miliki. Pembelajaran biologi memerlukan kegiatan penyelidikan/eksperimen sebagai bagian dari kerja ilmiah yang melibatkan ketrampilan proses yang dilandasi sikap ilmiah. Pembelajaran Biologi mengembangkan rasa ingin tahu melalui penemuan/inkuiri berdasarkan pengalaman langsung yang dilakukan melalui kerja ilmiah untuk mendapatkan fakta, membangun konsep, prinsip, teori, dan hukum (BSNP, 2006). Pembelajaran Biologi sama halnya dengan pembelajaran sains, memiliki hakikat yang berbeda dengan hakikat pembelajaran lain. Hakikat pembelajaran sains adalah pembelajaran yang mampu merangsang kemampuan berpikir peserta didik meliputi empat unsur utama yaitu sikap, proses, produk, dan aplikasi (Rustaman, 2005). Model PBL merupakan salah satu model pembelajaran berbasis masalah yang berlandaskan pada paradigma konstruktivisme yang sangat mementingkan peserta didik dan berorientasi pada proses belajar peserta didik (student centered learning). Pembelajaran diharapkan menjadi lebih bermakna dengan penggunaan model $P B L$, sehingga bisa meningkatkan hasil belajar peserta didik. Menurut Boud dan Felleti (dalam Wena, 2009), strategi belajar berbasis masalah merupakan suatu pendekatan pembelajaran dengan membuat konfrontasi kepada peserta didik dengan masalah-masalah praktis, berbentuk ill-structured atau open-ended melalui stimulus dalam belajar. Penelitian ini bertujuan untuk mengetahui ada tidaknya peningkatan kualitas proses dan hasil pembelajaran materi sistem pernapasan pada peserta didik kelas XI MIPA 6 SMA Negeri 1 Tawangsari semester 2 tahun pelajaran 2017/2018 dengan penerapan model PBL.

\section{Metode Penelitian}

Penelitian ini adalah Penelitian Tindakan Kelas. Subyantoro (2017: 28) menyatakan bahwa PTK dilaksanakan secara kolaboratif antara guru dengan pihak-pihak lain yang bertujuan untuk meningkatkan kinerja guru serta hasil belajar peserta didik. Penelitian 
Tindakan Kelas ini bertujuan untuk memecahkan masalah yang terjadi di dalam kelas. Penelitian ini dilakukan di kelas XI MIPA 6, SMA Negeri 1 Tawangsari pada semester 2 Tahun Pelajaran 2017/2018. Tahap persiapan sampai dengan pelaporan hasil penelitian dilakukan selama enam bulan, yakni bulan Januari sampai dengan Juni 2018. Subjek penelitian adalah peserta didik kelas XI MIPA 6 yang berjumlah 38 peserta didik yang terdiri dari 29 perempuan dan 9 laki-laki. Penelitian Tindakan Kelas ini dilaksanakan dalam dua siklus, dimana setiap siklus terdiri dari dua pertemuan. Setiap siklus melalui proses berdaur yang mencakup empat tahap, yaitu: tahap perencanaan $(\mathrm{P})$, pelaksanaan tindakan $(\mathrm{T})$, pengamatan atau observasi $(\mathrm{O})$, dan refleksi $(\mathrm{R})$.

Teknik pengumpulan data menggunakan teknik tes, observasi, dan dokumentasi. Data diuji validitasnya dengan menggunakan beberapa teknik yaitu dengan triangulasi sumber data dan triangulasi metode. Teknik analisis yang digunakan dalam penelitian ini adalah teknik analisis kritis dan teknik analisis deskriptif komparatif. Analisis kritis berkaitan dengan data yang bersifat kualitatif. Data analisis kritis berupa hasil observasi dan wawancara. Data yang berupa deskriptif komparatif yaitu teknik yang digunakan untuk data kuantitatif yakni membandingkan antarsiklus. Data ini berupa motivasi, keaktifan, hasil tes yang sudah dikerjakan oleh peserta didik. Peneliti membandingkan hasil sebelum penelitian dengan hasil di setiap siklusnya.

\section{Hasil Penelitian}

Berdasarkan tes kemampuan awal yang sudah dilaksanakan diperoleh hasil sebagai berikut: peserta didik yang nilainya sudah mencapai kriteria ketuntasan minimal (di atas KKM) sebanyak 21 peserta didik (55,26\%), sedangkan 17 peserta didik (44,74\%) nilainya masih di bawah KKM. Nilai tertinggi yang diperoleh adalah 80, dan nilai terendah 50 dengan nilai rata-rata 69,74. Peserta didik yang memiliki motivasi tinggi dan aktif mengikuti kegiatan pembelajaran sebanyak 12 peserta didik (31,58\%). Diharapkan pada siklus I kualitas proses pembelajaran dan ketuntasan klasikal akan mengalami kenaikan. Berdasarkan observasi pada siklus I, peserta didik yang memiliki motivasi tinggi (termotivasi) dalam kegiatan pembelajaran sebanyak 27 peserta didik $(71,05 \%)$, peserta didik yang motivasinya masih rendah sebanyak 11 peserta didik $(28,95 \%)$, peserta didik yang terlihat aktif dalam pembelajaran sebanyak 25 peserta didik $(65,79 \%)$, dan peserta didik yang belum aktif sebanyak 13 peserta didik (34,21\%.) Nilai rata-rata kelas pada siklus I ini adalah 74,08 dengan nilai tertinggi 85 dan nilai terendah 60 . Ketuntasan klasikal pada siklus I mencapai $68,42 \%$ (26 peserta didik), sedangkan 12 peserta didik (31,58\%) belum tuntas, sehingga masih perlu tindakan pada siklus berikutnya dengan beberapa perbaikan.

Siklus II merupakan kelanjutan pada siklus I yang mana pada siklus I belum mencapai indikator yang telah ditetapkan yaitu ketuntasan klasikal $\geq 75 \%$. Hasil akhir yang diperoleh pada siklus I dipakai sebagai acuan dalam melaksanakan siklus II. Pada siklus II, nilai rata-rata peserta didik sebesar 80,00 dengan nilai tertinggi 90 dan nilai terendah 70. Ketuntasan klasikal pada akhir siklus II ini mencapai 86,84\% (33 peserta didik), sedangkan yang belum tuntas sebanyak 5 peserta didik (13,16\%). Berdasarkan hasil observasi peserta didik yang memiliki motovasi tinggi sebanyak 35 peserta didik (92,11\%), yang belum termotivasi sebanyak 3 peserta didik (7,90\%), sedangkan peserta didik yang 
aktif sebanyak 34 peserta didik $(89,47 \%)$, dan yang belum aktif dalam pembelajaran sebanyak 4 peserta didik $(10,53 \%)$.

\section{Pembahasan}

Sebelum melakukan siklus I, peneliti melakukan survai awal untuk mengetahui kondisi yang ada di kelas XI MIPA 6 SMA Negeri 1 Tawangsari. Dari kegiatan survai awal ini peneliti menemukan bahwa kualitas hasil pembelajaran materi sistem pernapasan di kelas XI MIPA 6 SMA Negeri 1 Tawangsari masih tergolong rendah dibandingkan dengan nilai pelajaran biologi kelas yang lainnya. Oleh karena itu, peneliti mengadakan diskusi dengan guru bidang studi biologi yang bersangkutan untuk mencari solusi dalam upaya mengatasi masalah tersebut, yaitu dengan menggunakan model pembelajaran PBL. Peneliti bersama guru kelas menyusun rencana pembelajaran guna melaksanakan siklus I. Siklus pertama merupakan tindakan awal memperbaiki pembelajaran materi sistem pernapasan dengan model pembelajaran PBL. Berdasarkan hasil pengamatan terhadap proses belajar mengajar materi sistem pernapasan pada siklus I masih terdapat kekurangan dan kelemahan.

Siklus II pada penelitian ini merupakan siklus terakhir. Siklus II dilaksanakan untuk mengatasi kelemahan dan kekurangan pada siklus I. Pada siklus ini guru bersama peneliti berupaya memperkecil kelemahan yang terjadi selama pembelajaran materi sistem pernapasan berlangsung. Pada siklus II ini pembagian kelompok dilakukan oleh guru secara heterogen berdasarkan nilai dan jenis kelamin. Dengan anggota kelompok yang heterogen proses diskusi untuk memecahkan masalah menjadi lebih lancar dan bisa selesai tepat waktu. Berdasarkan peningkatan hasil pembelajaran yang terjadi pada siklus II membuktikan bahwa penerapan model pembelajaran PBL dapat meningkatkan kualitas proses maupun kualitas hasil pembelajaran materi sistem pernapasan pada peserta didik Kelas XI MIPA 6 SMA Negeri 1 Tawangsari.

Keberhasilan pembelajaran dengan model PBL dalam upaya meningkatkan kualitas proses dan kualitas hasil belajar materi sistem pernapasan dapat dilihat pada indikatorindikator yang sudah ditetapkan. Peningkatan kualitas proses pembelajaran dilihat dari motivasi dan keaktifan peserta didik. Penentuan presentase motivasi dan keaktifan dihitung dari jumlah peserta didik yang mendapatkan nilai minimal KKM 75 pada masing-masing indikator selama kegiatan pembelajaran. Adapun peningkatan kualitas proses pembelajaran dalam pelaksanaan tindakan siklus I dan II yang dibandingkan dengan prasiklus dapat digambarkan pada rekapitulasi data dalam bentuk tabel dan grafik berikut ini.

Tabel 1. Peningkatan Motivasi dan Keaktifan Peserta Didik Prasiklus, Siklus I dan Siklus II

\begin{tabular}{cllc}
\hline Perilaku & \multicolumn{3}{c}{ Persentase } \\
\cline { 2 - 4 } & Prasiklus & Siklus I & Siklus II \\
\hline Motivasi peserta didik selama pembelajaran & 31,58 & 71,05 & 92,11 \\
\hline Keaktifan peserta didik selama pembelajaran & 31,58 & 65,79 & 89,47 \\
\hline
\end{tabular}




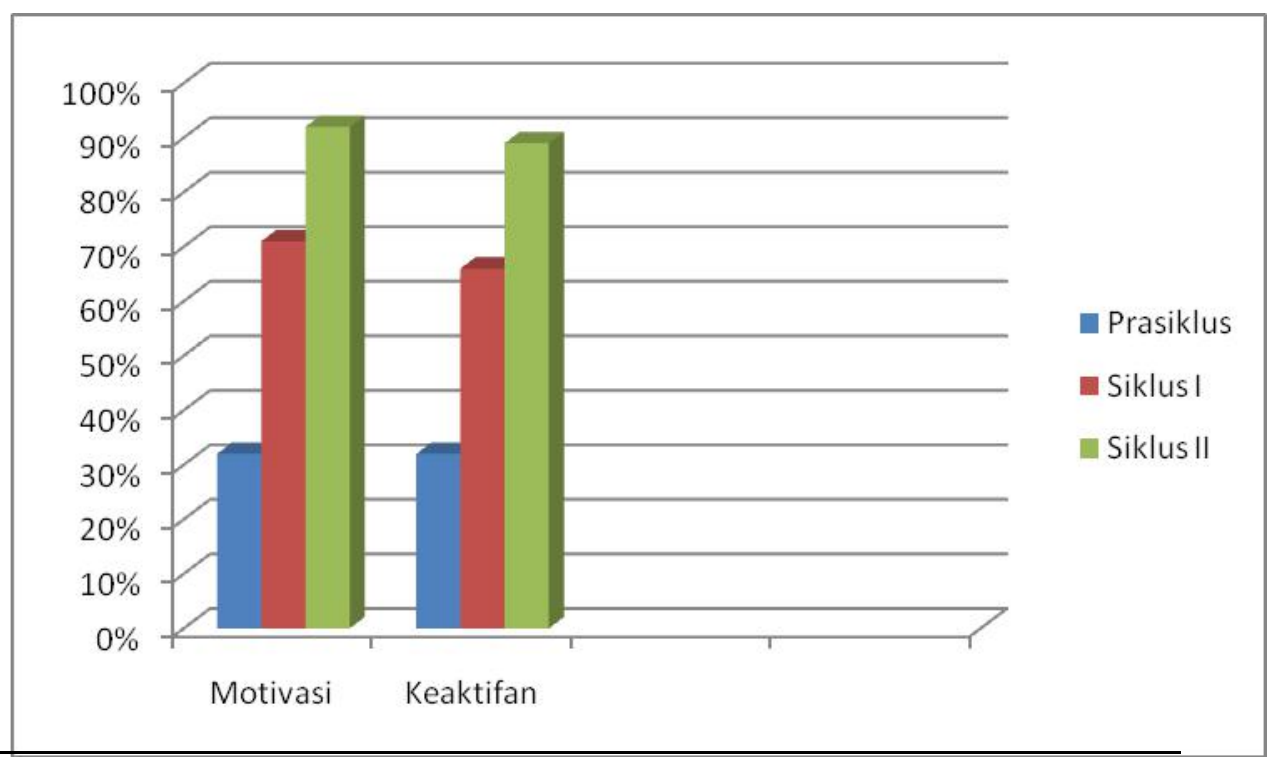

Gambar 1. Peningkatan Motivasi dan Keaktifan Peserta Didik pada Prasiklus,

Siklus I dan Siklus II

Hasil belajar peserta didik dalam pembelajaran materi sistem pernapasan pada penelitian ini meningkat setelah peserta didik mengikuti pembelajaran dengan penerapan model pembelajaran PBL. Dalam pembelajaran peserta didik tampak memperhatikan penjelasan yang dilakukan oleh guru, serta memahami dan menjawab pertanyaan dengan baik. Hal tersebut dapat dilihat dari tabel berikut ini.

Tabel 2. Peningkatan Hasil Belajar Peserta Didik Prasiklus, Siklus I, dan Siklus II

\begin{tabular}{cccc}
\hline & Hasil Belajar & \multicolumn{3}{c}{ Persentase } \\
\cline { 2 - 4 } No. & Prasiklus & Siklus I & Siklus II \\
\hline 1. & Tuntas & 68,42 & 86,84 \\
\hline & & & \\
\hline
\end{tabular}

Gambar 2. Peningkatan Hasil Belajar Peserta Didik padaPrasiklus, Siklus I, dan Siklus II 
Berdasarkan pengamatan selama tindakan siklus I dan II diperoleh nilai rata-rata hasil belajar 74,08 dengan ketuntasan belajar $68,42 \%$ kemudian pada siklus II rata-rata hasil belajar mengalami peningkatan menjadi 80 dengan ketuntasan belajar $86,84 \%$. Hasil tindakan pada siklus I dan siklus II tersebut lebih baik jika dibandingkan dengan hasil belajar pada saat prasiklus yaitu dengan rata-rata hasil belajar 69,74 dengan ketuntasan belajar 55,26\%. Berdasar hasil belajar tersebut dapat dikatakan bahwa peneliti berhasil dalam menerapkan model pembelajaran PBL. Model pembelajaran PBL merupakan model pembelajaran yang memberikan permasalahan kepada peserta didik untuk diselesaikan. Proses-proses dalam menyelesaikan masalah tersebut dapat memberikan sarana kepada peserta didik untuk melakukan penyelidikan dan inkuiri. Melalui penyelidikan tersebut peserta didik mendapatkan pengalaman belajar dan pengetahuan. Hal ini relevan dengan teori belajar Bruner bahwa belajar penemuan akan memberikan pengetahuan yang benarbenar bermakna. Pembelajaran yang bermakna tersebut juga sesuai dengan teori belajar Ausubel. Dahar (2011) mengemukakan bahwa belajar bermakna merupakan suatu proses dikaitkannya informasi baru pada konsep-konsep relevan yang terdapat dalam struktur kognitif seseorang.

Model PBL juga relevan dengan teori belajar Piaget karena proses-proses pembelajaran dalam PBL akan membantu perkembangan kognitif peserta didik. Kegiatankegiatan peserta didik dalam PBL yaitu merumuskan masalah, menyusun hipotesa, membuat rancangan percobaan, melakukan eksperimen, dan membuat kesimpulan. Kegiatan-kegiatan tersebut membantu peserta didik secara aktif untuk membangun sistem makna dan pemahaman realitasnya. Pada saat peserta didik memecahkan permasalahan melalui eksperimen, peserta didik memperoleh pengetahuan melalui pengalaman belajarnya yang kemudian diasimilasikan ke dalam pengetahuan yang sudah ada sebelumnya menjadi pengetahuan yang baru. Akcay (2009) juga sudah meneliti bahwa model PBL merupakan salah satu contoh dari lingkungan belajar konstruktivis.

Berdasarkan pengamatan yang sudah dilakukan peneliti, siklus yang dilaksanakan guru dengan penerapan model pembelajaran $\mathrm{PBL}$ dalam pembelajaran materi sistem pernapasan dapat meningkatkan kemampuan peserta didik, pembelajaran menjadi lebih menarik dan menyenangkan. Motivasi dan keaktifan peserta didik, serta hasil belajar peserta didik mengalami peningkatan. Hal ini sejalan dengan simpulan Wulandari dkk. (2014), bahwa penerapan model $P B L$ dalam pembelajaran biologi dapat meningkatkan aktivitas dan hasil belajar peserta didik. Keberhasilan tersebut dikarenakan tahapan-tahapan pada model pembelajaran PBL membantu peserta didik untuk dapat memahami materi sistem pernapasan dengan baik. Keberhasilan tersebut juga tidak lepas dari peran guru dalam mengelola kelas. Pengelolaan tersebut berupa memotivasi peserta didik, mendorong keaktifan peserta didik, mengawasi peserta didik ketika pembelajaran berlangsung, serta memberikan penghargaan kepada peserta didik.

\section{Simpulan dan Saran}

Berdasarkan hasil penelitian tindakan kelas yang telah dilaksanakan dua siklus dengan penerapan model PBL dalam pembelajaran biologi materi sistem pernapasan bagi peserta didik kelas XI MIPA 6 SMA Negeri 1 Tawangsari semester 2 dapat meningkatkan kualitas proses pembelajaran dan hasil belajar peserta didik. Hal ini dapat ditunjukkan dengan peningkatan motivasi ( $71,05 \%$ pada siklus I dan $92,11 \%$ pada siklus II) dan 
keaktifan peserta didik (65,79\% pada siklus I, dan 89,47\% pada siklus II), serta ketuntasan peserta didik (68,42\% pada siklus I, dan $86,84 \%$ pada siklus II).

Berdasarkan penelitian yang telah dilakukan, maka peneliti memberikan saran bagi guru yang akan melaksanakan pembelajaran melalui model PBL hendaknya selalu memonitor dan membimbing peserta didik yang mengalami kesulitan dalam menyelesaikan permasalahan pada proses pembelajaran, dan memperhatikan alokasi waktu agar semua sintaks $P B L$ bisa berlangsung dengan baik.

\section{Daftar Rujukan}

Abdurrohman, M. (2003). Pendidikan Anak Berkesulitan Belajar. Bandung: Sinar Baru.

Akcay, B. (2009). Problem-Based Learning in Science Education. Journal of Turkish Science Education, 6 (1), 26-36.

Aunurrahman. (2009). Belajar dan Pembelajaran. Bandung: Alfabeta.

Azwar, S. (2007). Metode Penelitian. Yogyakarta: Pustaka Buku.

BSNP. (2006). Petunjuk Teknis Pengembangan Silabus dan Contoh/Model Silabus $S M A / M A$. Jakarta: Depdiknas.

Dahar, R. W. (2011). Teori Teori Belajar dan Pembelajaran. Jakarta: Erlangga.

Hariatik, Suciati, Sugiyarto. (2017). Pembelajaran Biologi Model Problem Based Learning (PBL) Disertai Dialog Socrates (DS) Terhadap Hasil Belajar Ditinjau Dari Kemampuan Memecahkan Masalah Kelas X. Jurnal Pendidikan Biologi, Volume 8, Nomor 2, Februari 2017. Hal: 45-51.

Nur, M. (2011). Model Pembelajaran Berdasarkan Masalah. Surabaya: Pusat Sains dan Matematika Sekolah Unesa.

Rustaman, N. (2005). Strategi Belajar Mengajar Biologi. Malang: Universitas Negeri Malang.

Sagala, S. (2011). Konsep dan Makna Pembelajaran. Bandung: Alfabeta.

Subyantoro. (2017). Penelitian Tindakan Kelas. Semarang: Farishma Indonesia.

Trianto. (2010). Mendesain Model Pembelajaran Inovatif-Progresif. Jakarta: Kencana.

Winataputra, U. S. (2008). Teori Belajar dan Pembelajaran. Jakarta: Universitas Terbuka.

Wena, M. (2009). Strategi Pembelajaran Inovatif Kontemporer: Suatu Tinjauan Konseptual Operasional. Jakarta: Bumi Aksara.

Wulandari, R., D.J.Santri, dan D. Zen. (2014). Penerapan Model Pembelajaran Problem Based Learning (PBL) pada Pembelajaran Biologi di SMA Negeri 14 Palembang. Jurnal PBL Siswa SMA. Hal: 46-53. 